\title{
Assessing Service-Learning
} Approach:

Semantic Meanings of Learning Outcomes and Student Experiences

Selin Türkel

izmir Uni. of Eco. Faculty of Communication

https:/lorcid.org/0000-0002-6590-5607

selin.turkel@ieu.edu.tr

Ebru Uzunoğ/u

Izmir Uni. of Eco. Faculty of Communication

https://orcid.org/0000-0002-9715-8415

ebru.uzunog/u@ieu.edu.tr

\author{
Pinar Umul Ünsal \\ Izmir Uni. of Eco. Faculty of Communication \\ https://orcid.org/0000-0001-6350-6824 \\ pinar.umul@ieu.edu.tr
}

\section{Abstract}

This study uncovers existing practices of service-learning (SL) in higher education institutions. This was achieved by an examination of 64 courses in Turkish universities with accessible learning outcomes. The study also incorporates a "best practice" case study, a communication campaign combatting hate speech against refugee children. A comparison was made of general learning outcomes and individual and community outcomes reported by 43 students enrolled in the course in which the campaign was executed. Both text-based learning outcomes and student interview data were subject to semantic network analysis. SL courses in general display a strong emphasis on learning through projects, but the case study results indicated an absence of important outcomes such as engagement and citizenship values. In other respects, these courses not only aimed at significant learning outcomes in cognitive and affective domains, but also at assisting the transfer of necessary communication skills. The study presents insights for development of higher education curricula and implications for further research.

Keywords: Service-learning, semantic network analysis, learning outcomes, student experiences, communication campaign

Received: 03.03.2021 - Accepted: 15.11.2021

http://ilefdergisi.ankara.edu.tr

ilef dergisi • ( 2021 - Özel Sayı - güz/autumn: 33-68

Araștırma makalesi DOI: 10.24955/ilef.1037956 


\title{
Hizmet Ederek Öğrenme
}

\section{Yaklașımının Değerlendirilmesi: Öğrenme Çıktları ve Öğrenci Deneyimlerinin}

\section{Semantik Anlamları}

\section{Selin Türkel}

Izmir Ekonomi Üniversitesi Iletișim Fakültesi

https://orcid.org/0000-0002-6590-5607

selin.turkel@ieu.edu.tr

\section{Ebru Uzunoğlu}

Izmir Ekonomi Üniversitesi Iletișim Fakültesi

https://orcid.org/0000-0002-9715-8415

ebru.uzunoglu@ieu.edu.tr

\author{
Pınar Umul Ünsal \\ Izmir Ekonomi Üniversitesi Iletișim Fakültesi \\ https://orcid.org/0000-0001-6350-6824 \\ pinar.umul@ieu.edu.tr
}

\section{Öz}

Bu çalıșma, yüksek öğretim kurumlarındaki mevcut hizmet ederek öğrenme uygulamalarını ortaya koymaktadır. Bu amaçla Türkiye'deki üniversitelerde sunulan ve erișilebilir öğrenme çıktıları bulunan toplam 64 ders incelemeye tabi tutulmuștur. Çalıșmada ayrıca mülteci çocuklara yönelik nefret söylemiyle mücadele eden bir iletișim kampanyası, "bașarılı uygulama" olarak örnek olay yaklașımıyla ele alınmıștır. Genel öğrenme çıktıları ile örnek olaya konu olan kampanyanın yürütüldüğü dersi alan 43 öğrencinin ortaya koyduğu bireysel ve toplumsal çıktılar karșılaștırılmıștır. Metin tabanlı öğrenme çıtıları ve öğrenci deneyimlerini içeren görüșme verileri anlamsal ağ analizine tabi tutulmuștur. Hizmet ederek öğrenme dersleri genel olarak proje yoluyla öğrenme üzerinde yoğunlașmakta, ancak örnek olay incelemesi sonuçlarında yer alan katılım ve vatandașlık değerleri gibi önemli kazanımları içermemektedir. Öte yandan bu dersler, bilișsel ve duyușsal alanlarda önemli öğrenme kazanımlarını hedeflemenin yanı sıra gerekli iletișim becerilerinin aktarılmasına da yardımcı olmaktadır. Çalıșma, yüksek öğretim müfredatının geliștirilmesine ilișkin içgörüler ve gelecek araștırmalar için çıkarımlar sunmaktadır.

Anahtar Sözcükler: Hizmet ederek öğrenme, anlamsal ă̆ analizi, öğrenme çıktıları, öğrenci deneyimleri, iletișim kampanyası

Makale geliș tarihi: 03.03.2021 - Makale kabul tarihi: 15.11.2021

http://ilefdergisi.ankara.edu.tr

ilef dergisi • ( 2021 - Özel Sayı • güz/autumn: 33-68

Research Article DOI: 10.24955/ilef.1037956 


\section{Theoretical Framework}

Amidst many societal developments, higher education had to adapt to the contemporary needs of the information age. With the process of democratization and improved accessibility of knowledge globally, its production and dissemination no longer depend on an institutional context. Therefore, it is important that approaches and perceptions in higher education adapt to the dynamics of the new educational ecosystem. From a traditional perspective, the primary purpose and responsibilities of universities center upon teaching and research (Geoghegan, O'Kane and Fitzgerald 2015, 258). With the increased attention to societal concerns, these functions and responsibilities are no longer limited to knowledge production and dissemination, but focus on graduating individuals competent in their areas of expertise. University graduates' general and universal competencies of communication and action will provide contributions at the local, regional, national levels, and at the global community level via global citizenship. This much-needed shift in higher education poses an intermingling of continuity, referring to a conventional, lecture-based approach, and change, referring to engaging with community and relevant stakeholders through problem solving in a real-life 
context (Swords and Kiely 2010, 149). Moving from the classroom to the site of these issues suggests a further dramatic change in the educational mindset (Qualters 2010, 95).

Global citizenship is a multifaceted conceptualization with diverse definitions depending on the context, covering political, social, economic, and cultural concerns (Oxley and Morris 2013). Considering this contested scope, this study considers global citizenship as an educational mindset encompassing certain competencies. Drawing upon McIntosh's (2005) assertion on a global citizen's required competencies, these should include the abilities of observation of the self and others, discovery of similarities and differences, a democratic view of the world, and comprehension of how language shapes reality and power relations. These qualities point to communication as a central aspect of meaning creation and negotiation, bringing social change through civic engagement and persuasive communication (Mukherjee, Pethiya and Khobung 2019), further spurring students into action on public issues. Global citizenship emphasizes mobilizing elements such as global awareness, social responsibility, and civic engagement (Schattle 2009). Accordingly, global awareness entails both introspective and extrospective perceptions; demanding a high sense of self-awareness as well as the ability to evaluate the world from different viewpoints. In a similar vein, these individuals should be aware of their local and global social responsibilities. Therefore, becoming global citizens or "ideal global graduates" requires the adoption of values such as openness, tolerance, respect, sensitivity and responsibility toward others (Lilley, Barker and Harris 2017). Civic engagement, which requires active participation in local, regional, national and global community issues, facilitates collective behavioral change and action.

Higher education institutions facilitate collective experience regarding aforementioned issues, which may influence students' everyday lives. This approach might be considered as a change not only for education for awareness, but also for "learning by doing". A noted twentieth century scholar, John Dewey, advocated learning by doing, which involved students in a more active role than in traditional approaches. He suggests, "Education is a development within, by, and for experience" (1938, 28); furthermore "there is an intimate and necessary relation between the processes of actual experience and education $(1938,20)$. Similarly, other scholars promote learning through projects (Stimson 1919) and learning by problem-solving (Lancelot 1944), and this discussion continues (Knobloch 2003; Georgi 2008, 111; do Amaral 2019; 
Alsbury, Kobashigawa and Ewart 2020, 115). Such learning approaches have been put into practice in the States and many European countries, and gained considerable significance over the past twenty years (Shellman and Turan 2006, 19). However, higher education institutions may fail to accomplish this challenging mission of internalizing knowledge on the students' side unless traditional learning styles are combined with a student-centric approach, so that traditional, lecture-based education with learner-centric, active approaches enhance one another.

A platform for creative and critical thinking, as well as real-life experiences can be created through experiential learning, which gives students an authentic opportunity to practice their academic competences and socially acquired skills as a basis for community service (Larson 2008, 93). The rise of student-centric teaching/learning approach centered upon on-site, outof-classroom based activities and experiences serves to "move the learning paradigm from a relatively static and controlled one-way knowledge transmission to more dynamic, interactive and less controlled knowledge co-creation" (Roberts 2015, 110). For continuity, experiential learning practices are incorporated into the traditional curricula; however, this involves experiences outside the classroom, either physically or contextually, where students practice learning by doing, taking on roles requiring continuous critical reflection (Conrad and Hedin 1982, 58). For this mission of higher education to support the effective internalization of knowledge, institutions need to adapt to the growing need of experiential learning. Building upon experiences acquired through problem-solving and project-based learning, long-term benefits are gained as university students, as global citizens, are able to make contributions to the community.

Higher education approaches have shifted towards focusing on global responsibility and civic engagement through the development of service-learning (SL) courses incorporating experiential learning practices. SL, defined as "in-context learning that connects specific educational goals with meaningful community service" (Berman 2006, 21), have become a staple of curricula since 1990s globally (Bringle and Hatcher 1999, 184), and integrated into formal education focusing on issues such as diversity, gender inequality, citizenship, children, elders, and disability (Hamel 2001; Hess Brown and Roodin 2001; Jones and Hill 2001; Eudey 2012; Richards, Wilson, and Eubank 2012; Birdwell, Scott, and Horley 2013). SL courses allow students and instructors to continuously reflect on the process and their progress, and also benefit collaborating organizations (Jackowski and Gullion 1998, 259). 
Unlike traditional curricula, SL courses enable students to practice newly acquired learnings in real-life settings (Lin et al. 2017, 71). Other benefits include enhancing interpersonal and intra-personal soft skills (Caspersz and Olaru 2017, 686) such as critical thinking, problem solving, teamwork, time management, and appreciation of different viewpoints. Communication skills, as the primary soft skill, are among the most crucial educational outcomes (Schulz 2008, 148), and these courses have been demonstrated to enhance skills such as giving presentations and public speaking (Tucker and McCarthy 2001), verbal and written communication (Hebert and Hauf 2015), critical listening (Gunning 2017), dialogue (Bingham and McNamara 2008) and empathetic communication (Maloney and Griffith 2013). SL courses can vastly contribute to the education in various majors that emphasize such skills. Furthermore, for students of communication, SL courses in curricula are essential for transferring theoretical learning into real-life practice (Soukup 1999, 22). In congruence with this vision, the meta-analysis on SL courses supports current actions towards integrating SL courses in communication programs (Novak, Markey and Allen 2007, 155).

The aforementioned discussions on the relationship between higher education and learning approaches reveal the lack of consensus on models and practices regarding student-community engagement. This study investigates two dimensions of SL integration into higher education curricula. First, patterns of continuities and changes in SL courses obtained from Turkish universities reveal a fuller picture of current implementations within academia. Second, findings of a particular SL course, as a case study, demonstrate student perceptions and attitudes toward individual and community outcomes. A novel methodological approach, semantic network analysis (SNA), was adopted to manifest the shared understandings within learning outcomes.

An advanced search on studies that conducted social network analysis for investigating SL approach was performed in the Web of Science database, revealing only three relevant studies. Valdes-Vasquez, Luxton and Ozbek (2020) utilized SNA in a mixed-method approach to assess learning outcomes of an overseas SL project addressing sustainability. The article is differentiated from this study by its a specific focus on sustainability and cultural awareness. Similarly, the study of Held et al. (2019) has a specific concentration on SL, namely examining health related practices such as clinical knowledge and procedural skills. However, the authors constructed a social network of required professional qualifications, whereas the present study addresses so- 
cial competencies interpreted via semantic network analysis. Another study, Kirby et al. (2018) focuses on rural health services, involving a social network of community partners whose relations are modelled as graphs, rather than establishing linguistic relationships revealing collective understandings in perceptions of students, as in this study.

Consequently, this study offers a methodological contribution to empirical studies on SL by capturing students' free expressions, seeking to address an observed literature gap. Additionally, the current study emphasizes the learning by doing approach, identifying student-oriented SL goals through a detailed case study of 'best practice'.

\section{Methodology}

Aiming to unveil continuities and changes within collective understandings of learning outcomes in SL courses in Turkish universities, three research questions are proposed:

$R Q 1$. What is the semantic frame of the shared meaning of learning outcomes?

RQ2. What is the semantic frame of the shared meaning of achieved social change? (community outcomes)

$R Q 3$. What is the semantic frame of the shared meaning of gained social competencies? (individual outcomes)

Liberman and Olmedo $(2017,156-157)$ define semantic meaning as "the relation between signs and their significates", i.e., a collection of semantic meanings is associated with individual interpretations influenced by beliefs, attitudes, and behavior. Sense can be made of tangible or intangible objects by creating relations and integrations in meaning networks (Schultz et al. 2012, 99). When two concepts are correlated through associative meanings in an individual's mental construct, their embodiment in terms of signifying words constitute a semantic network, "a graphical representation of concepts in a relational way" (Shahzadi and Shaheen 2011, 1), which reveals and visualizes shared interpretations of any message content (Smart et al. 2010, 1). In this study, SNA is applied to explore connections and patterns in the collective understandings of learning outcomes, and in the shared meanings of individual and community outcomes derived from student interviews. Additionally, SNA captures the authentic language of respondents, resulting in natural, richer and large volumes of data, and reducing human bias in coding (Danowski 1993, 219). 
All networks in this study are illustrated with the number of nodes (or vertices) and lines, network density and average degree centrality. Nodes, smallest network units, represent associations of outcomes in the networks (e.g. "Prepares projects for the solution of social problems"), whereas lines are ties between nodes referring to connections, signaling relationships between outcomes (e.g. total number of lines is 1049 in the network; see Table 2). Percentage of total possible connections within a network is defined by density (De Nooy, Mrvar and Batagelj 2011, 73).

\section{Sample Selection, Procedure and Data Analysis}

To address RQ1, a search was performed of predetermined keywords frequently used for SL courses (social responsibility course, volunteer course, civic participation course, community service course) for selected Turkish universities listed in the 2020-2021 University Ranking by Academic Performance (URAP). ${ }^{1} 64$ courses with a total of 356 accessible learning outcomes were included in the final analysis. The sample consists of 23 state and 10 foundation universities from 16 cities in Turkey, ranking from 1 to 144 in the URAP list. Table 1 shows the distribution of courses according to universities (See Appendix 1).

The case study centers upon an SL course designed to help students develop an advocacy campaign, named See Like a Child (SLC - Çocuk Gibi Bak in Turkish). Semi-structured interviews were conducted with 43 out of 45 students enrolled in the SLC course in the fall and spring semesters during the 2018-2019 academic year. Participants were 25 and 18 male students, aged between 21-30, most from the middle/high-income SES groups.

As a projective technique, students were asked to perform sentence completion for below statements to obtain answers to RQ2 and RQ3:

- $\quad$ SLC project offers solutions for... (community outcomes)

- $\quad$ SLC course contributes to my life in ways such as... (individual outcomes)

Ethical standards demanded that interviewees were assured about the confidentiality of recordings and obtained information via voice confirmation during the interviews. Learning outcomes and student interview data were subject to SNA to reveal shared meanings. All authors conducted the coding, •.•

1 https://newtr.urapcenter.org/Rankings/2020-2021/2020-2021-T\%C3\%BCm\%20

$\% \mathrm{C} 3 \% 9$ Cniversitelerin $\% 20 \mathrm{Genel} \% 20 \mathrm{Puan} \% 20$ Tablosu 
through discussion and consensus, and only the outcomes bearing the same meaning were grouped and replaced. SNA aims to capture the authenticity of respondent data, and care was taken not to over-code the outcomes. Semantic network analysis was performed using Pajek software, ${ }^{2}$ a free and opensource software, which can process and visualize large network datasets.

\section{Findings of Turkish Universities' Learning Outcomes Network}

Pajek software was utilized to analyze text-based data of learning outcomes and compute measures of centrality, clique, and core structures in the semantic network.

Table 2: General characteristics of learning outcomes network

\begin{tabular}{|l|c|}
\hline Number of nodes & 213 \\
\hline Number of lines & 1049 \\
\hline Number of lines with value=1 & 897 \\
\hline Number of lines with value\#1 & 152 \\
\hline Density & 0.023 \\
\hline Average degree & 9.849 \\
\hline
\end{tabular}

Table 2 indicates 213 nodes identified in the learning outcomes network. The number of connections between nodes is 1049, which correspond to relations between statements. 897 lines have the value 1 is, and 152 have the value more than 1 . The density score is 0.023 , indicating a loosely-knit network. Such a low density demonstrates richness of data in terms of avoidance of over-coding and encouragement of free associations from participants (Lopez, Zhao and Tucker 2019). The average degree, which displays the average number of links attached to a node, is 9.849 .

Learning outcomes of SL courses in Turkish universities are presented in Table 3 in alphabetical order. The analysis included the five highest values of each centrality measure, with the highest value being 1.000. "Presents the project" has the highest value for in-degree measure. Top ranking node for out-degree, out-closeness and betweenness centralities is "Prepares projects for the solution of social problems". "Gains skills such as teamwork, entrepreneurship and communication" holds the highest value for in-closeness. This node was also found to be the network articulation point, i.e., the node that most significantly increases the number of connected components. Removing this node would split the graph into three sections. As a fully connected sub-

2 http://mrvar.fdv.uni-lj.si/pajek/ 
graph, the clique structure consists of three nodes: "Becomes aware of his/her responsibilities towards the society and the world he/ she lives in", "Becomes aware of social and current problems" and "Prepares projects for the solution of social problems".

Table 3: Semantic network of learning outcomes: Values of centrality

\begin{tabular}{|c|c|c|c|c|c|}
\hline Node & In-degree & Out-degree & $\begin{array}{l}\text { In-close- } \\
\text { ness }\end{array}$ & $\begin{array}{l}\text { Out- } \\
\text { closeness }\end{array}$ & $\begin{array}{l}\text { Between- } \\
\text { ness } \\
\text { Centrality }\end{array}$ \\
\hline $\begin{array}{l}\text { Becomes aware of social and } \\
\text { current problems. }\end{array}$ & - & 0.7500 & - & 0.9414 & 0.4148 \\
\hline $\begin{array}{l}\text { Develops positive attitude } \\
\text { towards voluntary participation } \\
\text { in community service activities. }\end{array}$ & - & 0.7857 & - & - & 0.3025 \\
\hline $\begin{array}{l}\text { Develops sensitivity towards } \\
\text { social problems. }\end{array}$ & 0.6364 & - & 0.8377 & - & 0.3903 \\
\hline Evaluates the project conducted. & 0.9394 & 0.6071 & 0.9117 & - & 0.4374 \\
\hline $\begin{array}{l}\text { Gains skills such as teamwork, } \\
\text { entrepreneurship and } \\
\text { communication. }\end{array}$ & 0.9091 & - & 1.0000 & - & 0.7227 \\
\hline $\begin{array}{l}\text { Learns the basic processes } \\
\text { involved in a social responsibility } \\
\text { campaign. }\end{array}$ & - & 0.6786 & - & - & 0.3305 \\
\hline Presents the project & 1.0000 & - & 0.9810 & - & 0.3050 \\
\hline $\begin{array}{l}\text { Takes part in various projects } \\
\text { related to social responsibility as } \\
\text { a volunteer. }\end{array}$ & - & - & 0.9281 & - & - \\
\hline $\begin{array}{l}\text { Understands the importance of } \\
\text { social responsibility activities. }\end{array}$ & - & 0.6071 & - & 0.9048 & 0.2215 \\
\hline $\begin{array}{l}\text { Creates social responsibility } \\
\text { awareness and self-confidence. }\end{array}$ & - & 0.6786 & - & 0.8211 & - \\
\hline $\begin{array}{l}\text { Defines basic concepts related } \\
\text { to social responsibility. }\end{array}$ & - & 0.6786 & - & 0.9274 & - \\
\hline $\begin{array}{l}\text { Explains the concept of social } \\
\text { responsibility. }\end{array}$ & - & 0.7143 & - & 0.9869 & - \\
\hline $\begin{array}{l}\text { Explains the concepts of } \\
\text { management, organization, } \\
\text { volunteering and volunteer } \\
\text { management. }\end{array}$ & - & 0.6786 & - & - & - \\
\hline $\begin{array}{l}\text { Implements a social } \\
\text { responsibility project. }\end{array}$ & 0.6970 & 0.6786 & 0.8063 & - & 0.4062 \\
\hline $\begin{array}{l}\text { Prepares projects for the } \\
\text { solution of social problems. }\end{array}$ & 0.8485 & 1.0000 & 0.9214 & 1.0000 & 1.0000 \\
\hline
\end{tabular}


Figure 1: M-Core of Turkish Universities' learning outcomes network

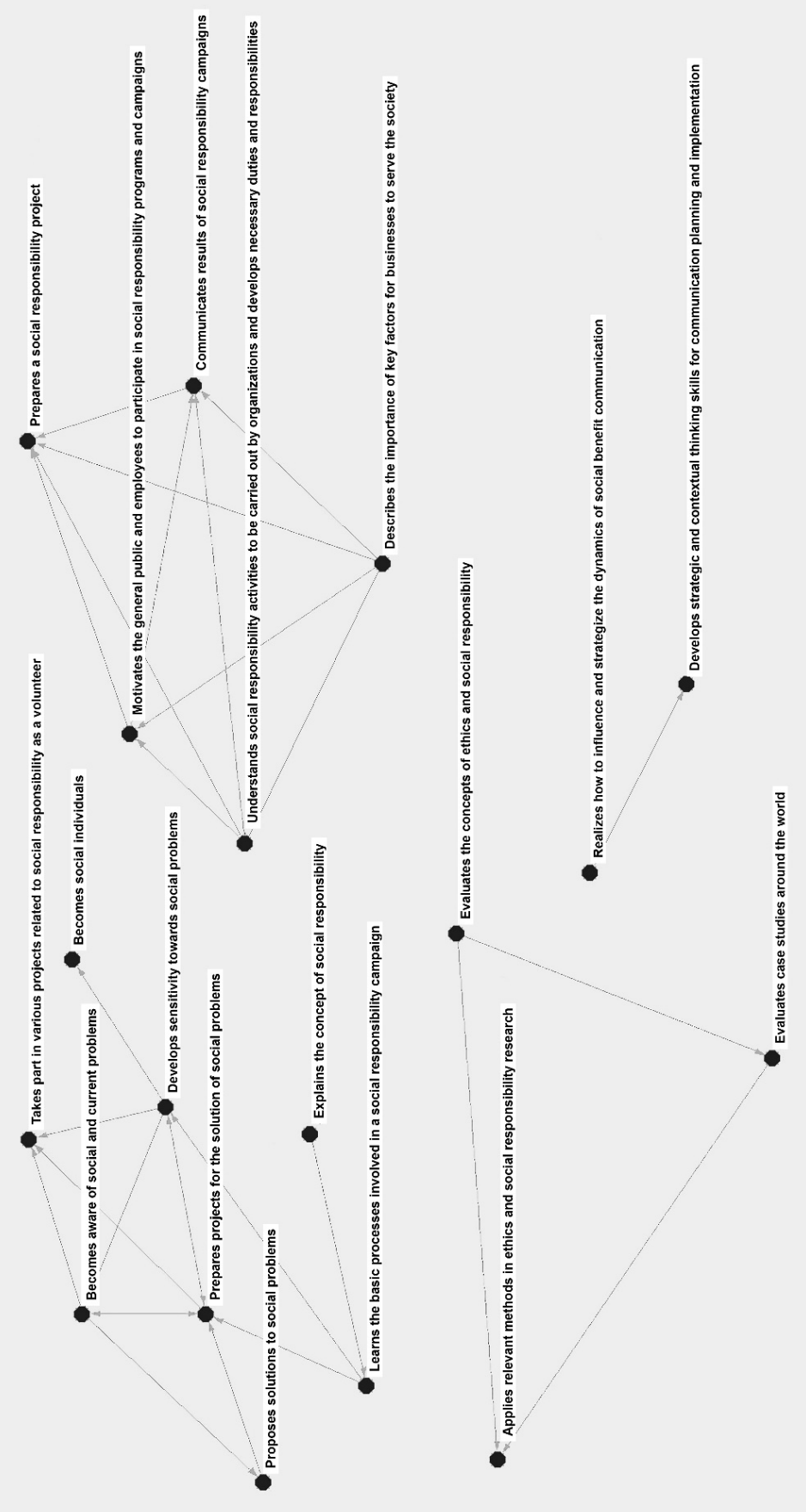


There is one connected m-core subgraph, a 4-core consisting of 18 statements (Fig.1) which indicate quite high number of associations. Yet, it should be notified that all associations were not present in other measures such as "Describes the importance of key factors for businesses to serve the society" or "Communicates results of social responsibility campaigns".

\section{Reflections on Turkish Universities' Learning Outcomes Network Findings}

In the learning outcomes network, some, but not all, outcomes were present in all measures. The number of repeats indicates the salience of nodes within a network. The table below shows the number of repeats within the learning outcomes network and presents the most common expressions of shared meanings regarding SL courses.

Table 4: Most repeated-measure statements for learning outcomes network

\begin{tabular}{|l|c|}
\hline Learning Outcomes & Repeat \\
\hline Prepares projects for the solution of social problems. & 7 \\
\hline Develops sensitivity towards social problems. & 5 \\
\hline Becomes aware of social and current problems. & 5 \\
\hline Evaluates the project conducted. & 4 \\
\hline Gains skills such as teamwork, entrepreneurship and communication. & 4 \\
\hline Implements a social responsibility project. & 4 \\
\hline Presents the project. & 3 \\
\hline Explains the concept of social responsibility. & 3 \\
\hline Learns the basic processes involved in a social responsibility campaign. & 3 \\
\hline Understands the importance of social responsibility activities. & 3 \\
\hline
\end{tabular}

The analysis of 64 SL courses validates the existence of experiential learning in Turkish universities. The most frequent statements revealed in Table 4, show a balance between outcomes addressing traditional, lecture-based learning, and those indicating experiential education endeavors. Learning by doing approach is distinctive, with different stages of project development, such as design, implementation, presentation and evaluation. The courses also demonstrate cognitive learning outcomes, e.g., explaining the concept of social responsibility and awareness of social problems, suggesting that students gain knowledge and cognitive strategies (Kraiger et al. 1993, 313). SL courses further attempt to raise sensitivity towards social problems, indicating affective outcomes that aim to induce motivation and attitudes (Farago, Shuffler, and Salas 2019, 261). As mentioned in the theoretical framework, SL courses serve as an enabler of technical and soft skills. 
The findings address the importance of skill-based outcomes, such as effective communication and cooperation, in congruence with expectations from the 21st century educational mindset (Gelen 2017, 19).

\section{A Case for Service-Learning: See Like a Child}

See Like a Child (SLC) may be considered as a best practice, being endorsed by Peer to Peer (P2P): Facebook Global Digital Challenge, and awarded as Fall 2018-2019 winner of the university students competition (Counterspeech Facebook, 2020), and also funded by Erasmus+ KA347 Structured Dialogue program. The case exemplifies how SL courses can support a global citizen mindset by providing students with a community service experience.

Contemporary official statistics demonstrated that 3,594,232 Syrians had migrated to Turkey since the civil war began in 2011 (GİG, 2018), the world's largest refugee population (UNHCR, 2019). The majority entered through the Turkish government's humanitarian asylum policy, but this generated considerable controversy, associated with negative attitudes within the host community. Collectively referred as 'Syrians', one significant, often overlooked group of refugees, and among them, children under 14 face the greatest difficulties. Government policies alone will not be sufficient to secure these children's long-term future, whether in Turkish society or any other place they choose to live. Against this background, SLC is the first social responsibility project initiated by university youth in Turkey, aiming to make young people aware that, while no child becomes a refugee by choice, the general public can choose their attitudes and relationship with them. The essence of this project focuses on the simple truth that 'a child is only a child', and the SLC's call to understand how these children see the world, and how they are seen by it.

$65 \%$ of Turkey's population is under the age of 35; thus, the advocacy campaign implemented within the SLC course, offered as a university elective, mainly targeted university students aged 18-25, with an extended scope of young urban adults aged 25-35. Near-past childhood experiences would allow university students to empathize with refugee children, resulting in better emotional responses (Duffy 1999, 104). Moreover, the target audience were the future parents, employers, and politicians, with the potential to steer social changes. Daily time spent on social media in Turkey is above the average, making it the $15^{\text {th }}$ country in the world (We Are Social, 2020). The campaign's target audience were heavy consumers of social media, highly competent in modern technology, ensuring more effective exposure for the campaign on 
social media, the core communication platform. Through social media, it was possible to reach socially aware youngsters and non-governmental organization (NGO) associations who value of diversity and richness of cultural differences, and the campaign was thus able to encourage their involvement with word-of-mouth potential.

Students enrolled in this course received significant training in communication with children and young people, as well as social pedagogy and children's rights, from experts from UNICEF, Turkish Red Crescent, Izmir Governorate and Municipality, and also from Maya Vakfı (Maya Foundation), which specifically works with children affected by war and migration trauma. The first stage of the project involved creating press bulletins and interviews, informative content, videos, film in social media and three photograph exhibitions, raising awareness on hate speech aimed at refugee children. Students enrolled in the course actively engaged with refugee children in out-of-classroom activities including watching basketball, creating a playground in the biggest mall of Izmir, an improvisation theater activity, and making cookies at a kitchen workshop. With consent of the families or relatives, recordings of these events were disseminated on social media, where interaction encouraged to further encourage the target audience. Important days for Turkey and the world were celebrated through messages drawing attention to refugee children's experiences in Turkey, and the target audience was encouraged to contribute their own positive childhood memories to the campaign's official social media.

Offline activities included a series of panels held with NGO staff, opinion leaders and celebrities. Students visited different university campuses in major cities with high refugee population to actively encourage a more positive perception of the children. A book donation campaign was also held. After two semesters of online and offline activities, a post-survey was conducted to track changes in awareness, mindset shift, and commitment, consistent with campaign objectives. In the course's second year, the aim was to exchange experiences with other countries experiencing similar refugee issues, and to propose international events and solutions. As part of an Erasmus+ project, university students from Italy, Greece, Spain and Portugal participated in five days of workshops, trainings and activities related to refugee children. At the end, partner universities prepared a declaration, presented to local decision makers. A pre and post-test conducted with participant students to measure the impact of SLC activities showed a clear reduction in the negative adjectives used to describe the refugee children. 


\section{Findings of SLC's Individual and Community Outcomes Networks}

Pajek was used to analyze interview data, consisting of individual and community outcomes, and calculate indicators, such as centrality measures, clique and core structures in the semantic network.

Table 5: General characteristics of community outcomes network

\begin{tabular}{|l|c|}
\hline Number of nodes & 24 \\
\hline Number of lines & 49 \\
\hline Number of lines with value=1 & 42 \\
\hline Number of lines with value\#1 & 7 \\
\hline Density & 0.089 \\
\hline Average degree & 4.083 \\
\hline
\end{tabular}

Learning outcomes network consists of 24 nodes and 49 lines. 42 lines had the value 1 and 7 had the value more than 1 , suggesting a loosely-knit network. Community outcomes network has fewer connections between statements and is of low density with a score of 0.089. Compared to the density of learning outcomes network (See Table 2), this network has a much lower density, with an average degree of 4.083 .

Student statements regarding community outcomes (SLC project offers solutions for...) are stated above in alphabetical order. Table 6 demonstrates the five highest values of each centrality measure, the highest being 1.000. "Ameliorating communication between society and refugee children" shares the highest value of in-degree with "Helping children connect with the general public", which also has the highest betweenness measures. "Overcoming a social problem" has the highest value for both out-degree and out-closeness. Among centrality measures, degree and closeness values are expected to be in highest correlation (Valente et al. 2008, 3). "Creating a space for people and children to spend time together" has the highest value for in-closeness. In this network, no clique or articulation points were observed. 
Table 6: Semantic network of community outcomes: Values of centrality

\begin{tabular}{|c|c|c|c|c|c|}
\hline Node & In-degree & $\begin{array}{c}\text { Out- } \\
\text { degree }\end{array}$ & $\begin{array}{l}\text { In-close- } \\
\text { ness }\end{array}$ & $\begin{array}{c}\text { Out-close- } \\
\text { ness }\end{array}$ & $\begin{array}{l}\text { Between- } \\
\text { ness } \\
\text { Centrality }\end{array}$ \\
\hline $\begin{array}{l}\text { Ameliorating communication } \\
\text { between society and refugee } \\
\text { children }\end{array}$ & 1.0000 & 0.5714 & 0.8861 & 0.6307 & 0.4803 \\
\hline $\begin{array}{l}\text { Breaking existing prejudices towards } \\
\text { the children }\end{array}$ & 0.5714 & 0.4286 & 0.9029 & - & 0.3947 \\
\hline $\begin{array}{l}\text { Contributing to the education of } \\
\text { children }\end{array}$ & 0.7143 & 0.2857 & 0.6816 & 0.5802 & 0.0724 \\
\hline $\begin{array}{l}\text { Creating a space for people and } \\
\text { children to spend time together }\end{array}$ & 0.7143 & - & 1.0000 & - & - \\
\hline $\begin{array}{l}\text { Developing an understanding } \\
\text { towards refugee children }\end{array}$ & 0.1429 & 0.5714 & 0.1947 & 0.7407 & 0.1711 \\
\hline $\begin{array}{l}\text { Enabling people to gain a different } \\
\text { perspective }\end{array}$ & 0.5714 & 0.5714 & 0.8513 & 0.5769 & 0.6645 \\
\hline Ending discrimination & - & - & 0.6283 & - & 0.2368 \\
\hline $\begin{array}{l}\text { Helping children connect with the } \\
\text { general public }\end{array}$ & 1.0000 & 0.5714 & 0.9327 & 0.7634 & 1.0000 \\
\hline Overcoming a social problem & 0.1429 & 1.0000 & 0.1947 & 1.0000 & 0.0921 \\
\hline $\begin{array}{l}\text { Providing benefit for the ones in } \\
\text { need }\end{array}$ & - & 0.2857 & - & 0.8242 & - \\
\hline
\end{tabular}

The biggest two m-core groupings were 2-core and 3-core that include 12 statements in total. The statements are presented in Figure 2, with 3-core values shown with bold nodes, "Enabling people to gain a different perspective" and "Breaking existing prejudices towards the children". 
Figure 2: M-Core of community outcomes network

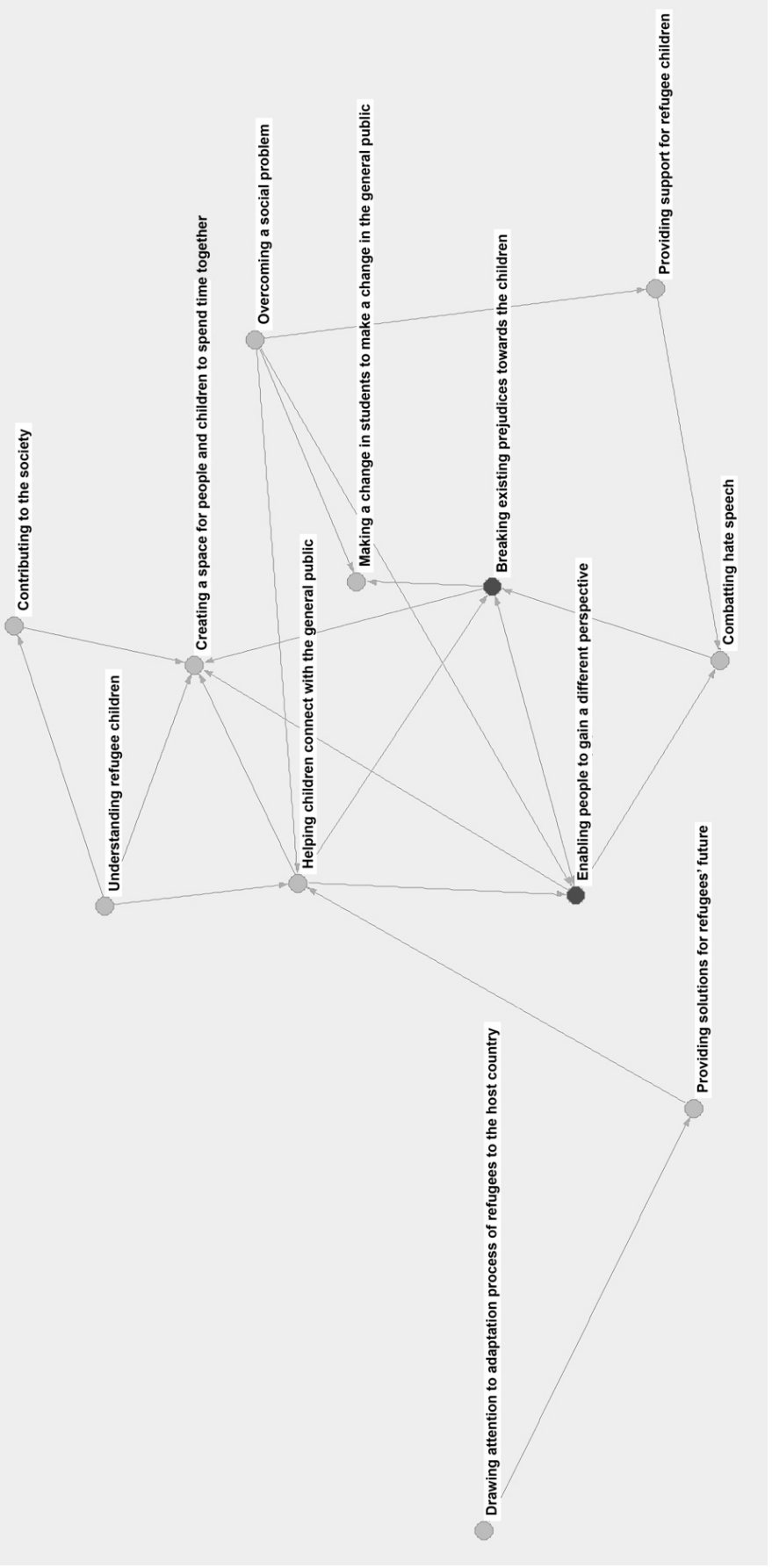


Table 7: General characteristics of individual outcomes network

\begin{tabular}{|l|c|}
\hline Number of nodes & 20 \\
\hline Number of lines & 43 \\
\hline Number of lines with value=1 & 29 \\
\hline Number of lines with value\#1 & 14 \\
\hline Density & 0.113 \\
\hline Average degree & 4.300 \\
\hline
\end{tabular}

The individual outcomes network has 20 nodes and 43 lines. 29 lines have the value 1 , and 14 have the value more than 1 . Density score (0.013) and average degree (4.300) are relatively higher than community outcomes network, indicating a slighter denser network.

Table 8: Semantic network of individual outcomes: Values of centrality

\begin{tabular}{|l|c|c|c|c|c|}
\hline & In-degree & Out-degree & $\begin{array}{c}\text { In- } \\
\text { closeness }\end{array}$ & $\begin{array}{c}\text { Out- } \\
\text { closeness }\end{array}$ & $\begin{array}{c}\text { Between- } \\
\text { ness } \\
\text { Centrality }\end{array}$ \\
\hline Breaking my own prejudices & 1.0000 & 0.5455 & 1.0000 & 0.6585 & 1.0000 \\
\hline Developing me & 0.6667 & 0.3636 & 0.7879 & 0.7941 & 0.8189 \\
\hline Helping me empathize more & 0.5000 & 0.0909 & 0.6667 & 0.4737 & 0.1301 \\
\hline $\begin{array}{l}\text { Helping me not to } \\
\text { discriminate because of } \\
\text { religion, language and race }\end{array}$ & 1.0000 & 0.0909 & 0.9630 & 0.4655 & 0.3827 \\
\hline $\begin{array}{l}\text { Helping me realize how } \\
\text { precious children are }\end{array}$ & 0.5000 & 0.0909 & 0.6341 & 0.3750 & 0.1301 \\
\hline $\begin{array}{l}\text { Helping me recognize the } \\
\text { feeling of happiness in doing } \\
\text { good }\end{array}$ & 0.6667 & 0.3636 & 0.7027 & 0.7105 & 0.5408 \\
\hline $\begin{array}{l}\text { Making me aware of this } \\
\text { social issue }\end{array}$ & 0.3333 & 0.2727 & 0.7222 & 0.6136 & 0.0000 \\
\hline $\begin{array}{l}\text { Providing me a different } \\
\text { point of view }\end{array}$ & 0.5000 & 1.0000 & 0.6667 & 1.0000 & 0.7245 \\
\hline Spending meaningful time & 0.3333 & 0.3636 & 0.5306 & 0.7714 & 0.4286 \\
\hline
\end{tabular}

Student statements for individual outcomes (SLC course contributes to my life in ways such as...) are presented above in alphabetical order. The table gives the first five values of each centrality measure. In terms of in-degree measure, "Helping me not to discriminate because of religion, language and race" shares the highest value with "Breaking my own prejudices", the latter also has the highest values for in-closeness and betweenness centrality. The 
table also indicates that "Providing me a different point of view" has the highest values both for out-degree and out-closeness, which are highly correlated, similar to the results of community outcomes. No clique or articulation points were found.

\section{Reflections on SLC's Community and Individual Outcomes Network Findings}

The findings support the assumptions regarding distinctive community and individual outcomes. Interview participants could freely articulate their course accomplishments. A key expectation from SL courses is the students' ability to generate contributions benefiting both the community and themselves (Steinberg, Bringle and McGuire 2013, 27).

Existing studies lack a specific stress on community outcomes of service learning (Reeb and Folger 2013, 389; Roodin, Brown and Shedlock 2013, 18). In this research, students stated that this project potentially leads to strengthening of community bonds with the children. Among the most common shared meanings in terms of achieved social change were community outcomes such as helping children connect with the public, bringing different perspectives towards this social issue, and ameliorating communication between society and the children.

Students asserted that participating in SLC campaign also made contributions to their social competencies; they were able to overcome to break their own prejudices, adopt a different viewpoint, and experience the fulfillment in doing good. The findings substantiate general expectations from SL courses regarding personal growth, and building self-consciousness around prosocial behavior, responsible citizenship, civic engagement and diversity (Butin 2003, 1677). In line with course objectives, statements regarding individual and community outcomes indicate fostering of both cognitive and affective changes, and active participation facilitated graduates' self-perceptions as global citizens, compassionate about world issues, and able to relate to people from diverse backgrounds. 
Figure 3: M-Core of individual outcomes network

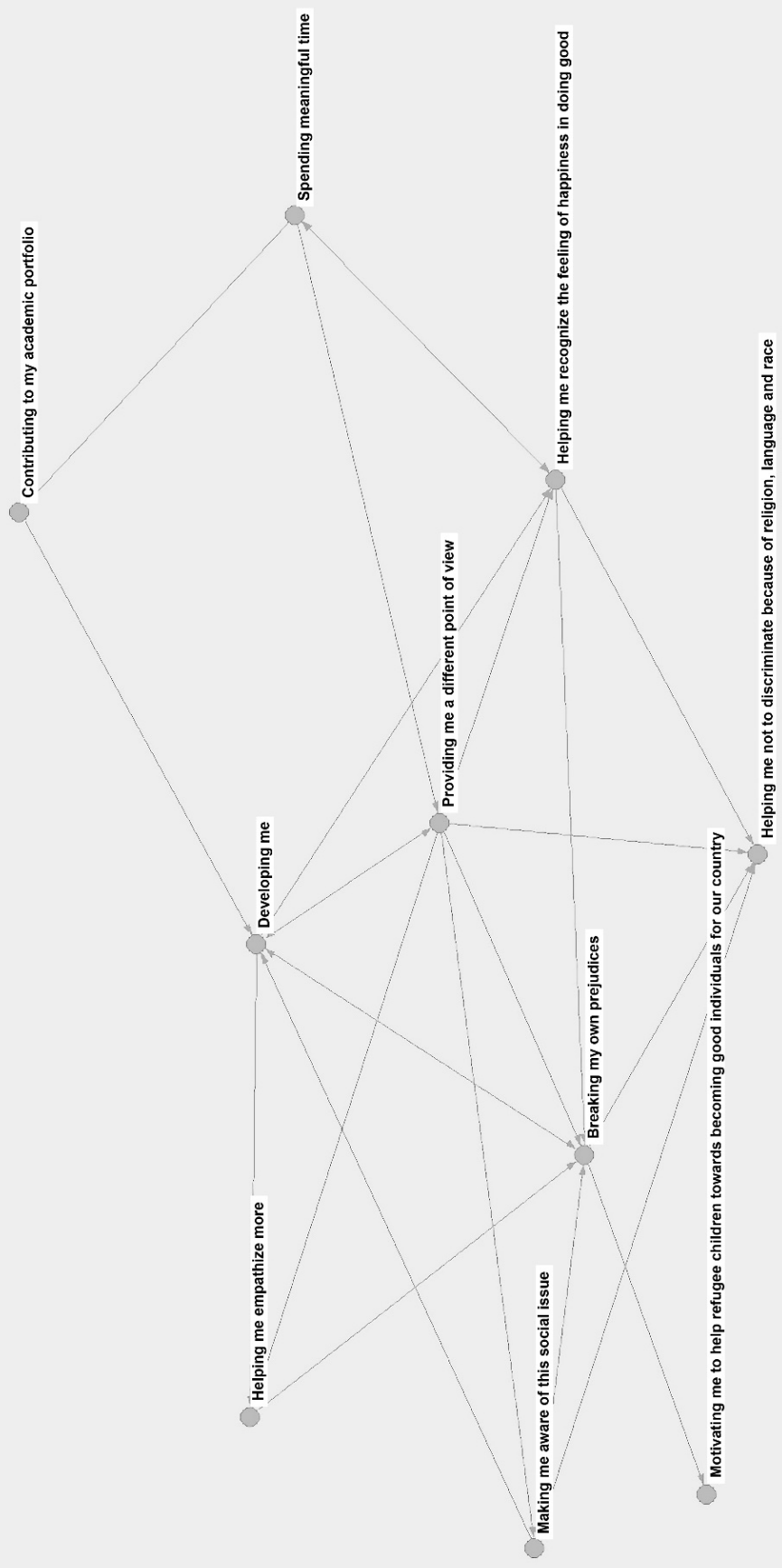


There is only one connected m-core subgraph, a 2-core consisting of 10 statements in which each statement is connected by lines of two as $m$, shown in Figure 3.

\section{Conclusion}

Service-learning elements among experiential learning practices are increasingly common in higher education curricula. The findings regarding learning outcomes highlight this emerging tendency in Turkish education system, with a focus on project-based learning blended with traditional, lecture-based approaches. Outcomes based on experiential learning, such as "Prepares projects for the solution of social problems", are more frequently repeated in the learning outcomes network. However, also present are outcomes that indicate lecture-based learning such as "Explains the concept of social responsibility". The learning outcomes network reveals a combination of traditional, lecturebased learning outcomes and experiential outcomes, referring to involvement with real-life community issues, providing evidence for continuity and change existing concurrently. Yet, shortfalls remain in terms of expectations regarding achievement in global citizenship and civic engagement, despite the evident advancements in experiential learning implementations.

Regarding the learning outcomes network, the most common shared meanings in SL courses centered on project development and implementation. Project-based learning, which touches upon social/cultural problems, is an effective method for delivering necessary knowledge and skills (Huff, Zoltowski and Oakes 2016, 44; Jia, Jung and Ottenbreit-Leftwich 2018, 264). According to Eyler and Giles, to be deemed successful, SL courses need to provide the following: "Personal and interpersonal development, understanding and applying knowledge, engagement, curiosity and reflective practice, critical thinking, perspective transformation and citizenship" (Schultz 1999, 142). Learning outcomes network reveal that the courses are deficient in the progress of competencies of engagement and citizenship behavior, despite supporting acquisition of basic knowledge regarding concepts such as social responsibility, volunteerism, civic participation and community service, and providing opportunity for personal and interpersonal development (teamwork and communication competencies) and perspective transformation (sensitivity towards social issues).

Individual and community outcomes from students' self-reported SLC course evaluation suggest a better correspondence to expectations in terms of 
personal and interpersonal development (an increased sense of empathy and personal progress, breaking prejudices), perspective transformation (gaining a different viewpoint both on individual and community levels), engagement (supporting children's connection with general public) and global citizenship values (opposing discrimination in favor of diversity). In a society with increasingly salient social issues and problems, higher education institutions will inevitably aim at producing global citizens. In this regard, the current study on SL courses in Turkey displays various achievements, but further steps remain. The case study illustrates that more comprehensive efforts are needed to meet Eyler and Giles' criteria of civic engagement, and citizenship values, and graduates should also gain communication competencies for advocating for diversity and equality.

Self-reported competencies may be influenced by social desirability, a limitation for all studies on SL (Celio, Durlak and Dymnicki 2011, 177). Individual outcomes articulated by students may be interpreted as future behavioral intentions; however, longitudinal studies are needed to confirm whether these outcomes in fact result in changed behaviors. Nevertheless, to the authors' knowledge, this was the first study to examine semantic attributes of interview data triggered by projective techniques, i.e., sentence completion, which can diminish bias in self-reporting (Lichtenstein et al. 2003, 839).

A case study elucidating complex student experiences constitutes unique theoretical contributions to the literature. Furthermore, SNA is considered an innovative technique in educational research (Slantcheva-Durst 2018, 27) and can contribute insights for higher education practices. SL courses provide dual benefits to students and the community, offering enhanced learning and establishing bonds between the institution and the community. In this era of increased competition in staff recruitment and attracting prominent students, universities need community outreach and contribution for competitive advantage and reputation (Dahan and Senol 2012, 95); learner-centric experiential courses can serve as a key component in this regard, and for creating social impact.

This study holds implications for further research. One is the potential for a cross-national investigation of possible influences of culture on learning outcomes and students' perceived accomplishments, which may shed light on countries sharing cultural traits, such as South Korea and China (Wang and Genç 2019, 55), or different cultural clusters, such as Eastern collective and Western individualist cultures. Another approach to cross-cultural research 
opportunities is to compare countries in terms of early or late urbanization and industrialization (Eser and Sarışahin 2016, 39-40) in terms of civic responsibilities and rights.

\section{Contributors}

Melis Gelişen, an MA student at Izmir University of Economics, helped the authors in conducting and transcribing the in-depth interviews and contributed to the interview data interpretation. 


\section{References}

Alsbury, Thomas L., Suzan Kobashigawa, and Mary Ewart. 2020. “Community-Based Learning: An Exploration from Philanthropy to Praxis" In Toward CommunityBased Learning, 95-123. Brill Sense. https:// doi.org/10.1163/9789004424494 002

Ban, Hyun-Jeong, and Hak-Seon Kim. 2019. "Semantic Network Analysis of Hotel Package Through the Big Data." Culinary Science \& Hospitality Research 25, no. 2: $110-119$.

https: / / doi.org/10.20878/ cshr.2019.25.2.014

Berman, Sally. 2006. Service Learning: A Guide to Planning, Implementing, and Assessing Student Projects. California: Corwin Press.

Bingham, Shereen G., and Patrick T. McNamara. 2008. "The Promise of Public Dialogue In Service-Learning Courses." Reflections 8.1. https: / / reflectionsjournal.net/wp-content/uploads/2019/10/V8.N1. Bingham.Shereen.pdf

Birdwell, Jonathan, Ralph Scott, and Edward Horley. 2013. "Active Citizenship, Education and Service Learning." Education, Citizenship and Social Justice 8, no. 2: 185-199. https: / / doi.org/10.1177/1746197913483683

Bringle, Robert G., and Julie A. Hatcher. 1999. “Reflection in Service Learning: Making Meaning or Experience." Educational Horizons (Spring): 179-185. https: / / digitalcommons.unomaha.edu/slceeval/23

Butin, Dan W. 2003. "Of What Use Is It? Multiple Conceptualizations of Service Learning Within Education." Teachers College Record 105, no. 9: 1674-1692. https: / / academic.macewan.ca/csl/files / 2014/04/Of-What-Use-Is-It Multiple-Conceptualizations-of-Service-Learning-Within-Education.pdf

Caspersz, Donella, and Doina Olaru. 2017. "The Value of Service-Learning: The Student Perspective." Studies in Higher Education 42, no. 4: 685-700. https: / / doi.org/10.1080/03075079.2015.1070818

Celio, Christine I., Joseph Durlak, and Allison Dymnicki. 2011. "A Meta-Analysis of The Impact of Service-Learning on Students." Journal of Experiential Education 34, no. 2: 164-181. https:// doi.org/10.1177\%2F105382591103400205 
Conrad, Daniel, and Diane Hedin. 1982. "The Impact of Experiential Education on Adolescent Development" In Youth Participation and Experiential Education, edited by Daniel Conrad and Diane Hedin, 57-76. New York: The Haworth Press.

Counterspeech Facebook. 2020. “Peer to Peer (P2P): Facebook Global Digital Challenge". Accessed January 16, 2021.

https:// counterspeech.fb.com/en/initiatives/p2p-facebook-global/

Dahan, Gresi Sanje, and Isil Senol. 2012. “Corporate Social Responsibility in Higher Education Institutions: Istanbul Bilgi University Case." American International Journal of Contemporary Research 2, no. 3: 95-103.

http://www.aijcrnet.com/journals/Vol 2 No 3 March 2012/10.pdf

Danowski, James A. 1993. “Network Analysis of Message Content." Progress In Communication Sciences 12: 198-221.

De Nooy, Wouter, Andrej Mrvar, and Vladimir Batagelj. 2011. Exploratory Social Network Analysis with Pajek. Cambridge: Cambridge University Press.

Dewey, John. 1938. Experience and education. New York: Collier Books.

do Amaral, João Alberto Arantes. 2019. “Combining Community-Based Learning and Project-Based Learning: A Qualitative Systemic Analysis of The Experiences and Perceptions of Students and Community Partners." Partnerships: A Journal of Service-Learning and Civic Engagement 10, no. 1: 129-145.

http:/ / libjournal.uncg.edu/prt/article/viewFile/1733/1306

Duffy, Karen G. 1999. Personal Growth and Behavior. McGraw-Hill/Dushkin.

Eser, Hamza Bahadır, and Pınar Sarışahin. 2016. “Cinsiyet-Siyasal Katılım İlişkisi: SDÜ Örnek Olayı." Süleyman Demirel Üniversitesi Vizyoner Dergisi 7, no. 15: 38-58.

https:/ / doi.org/10.21076/vizyoner.252105

Eudey, Betsy. 2012. "Civic Engagement, Cyberfeminism, and Online Learning:

Activism and Service Learning in Women's and Gender Studies Courses." Feminist Teacher 22, no. 3: 233-250.

https:// doi.org/10.5406/femteacher.22.3.0233

Farago, Pamela, Marissa L. Shuffler, and Eduardo Salas. 2019. "The Design, Delivery, and Evaluation of Crew Resource Management Training." In Crew Resource Management, 251-282. Academic Press.

https: / / doi.org/10.1016/B978-0-12-374946-8.10007-X 
Gelen, İsmail. 2017. “P21-Program ve Öğretimde 21. Yüzyıl Beceri Çerçeveleri (ABD Uygulamaları)." Disiplinlerarası Ĕ̆itim Araştırmaları Dergisi 1, no. 2: 15-29. https:// dergipark.org.tr/en/download/article-file/386403

Geoghegan, Will, Conor O’Kane, and Ciara Fitzgerald. 2015. “Technology Transfer Offices as A Nexus Within the Triple Helix: The Progression of the University's Role." International Journal of Technology Management 68, no. 3-4: 255-277. https:// doi.org/10.1504/IJTM.2015.069660

Georgi, Viola B. 2008. "Citizens in The Making: Youth and Citizenship Education in Europe." Child Development Perspectives 2, no. 2: 107-113. https:// doi.org/10.1111/j.1750-8606.2008.00050.x

GİGM. 2018. Göç İdaresi Genel Müdürlügüu. Accessed February 18, 2019. http://www.goc.gov.tr/icerik6/gecicikoruma_363_378_4713_icerik

Gunning, Sarah K. 2017. "Testing Methods of Promoting Critical Listening Skills in the Service Learning Classroom." In Proceedings of the 35th ACM International Conference on the Design of Communication, 1-6. https: / / doi.org/10.1145/3121113.3121222

Hamel, Pauline C. 2001. “Interdisciplinary Perspectives, Service Learning, and Advocacy: A Nontraditional Approach to Geriatric Rehabilitation." Topics in Geriatric Rehabilitation 17, no. 1: 53-70.

Hebert, Ali, and Petra Hauf. 2015. “Student Learning Through Service Learning: Effects on Academic Development, Civic Responsibility, Interpersonal Skills and Practical Skills." Active Learning in Higher Education 16, no. 1: 37-49. https: / / doi.org/10.1177\%2F1469787415573357

Held, Fabian P., Chris Roberts, Michele Daly, and Claire Brunero. 2019. “Learning Relationships in Community-Based Service-Learning: A Social Network Analysis." BMC Medical Education 19, no. 1: 1-10. https: / / doi.org/10.1186/s12909-019-1522-1

Hess Brown, Paul A. Roodin, Laura. 2001. “Service-Learning in Gerontology: An OutOf-Classroom Experience.” Educational Gerontology 27, no. 1: 89-103. https: / / doi.org/10.1080/036012701750069067

Huff, James L., Carla B. Zoltowski, and William C. Oakes. 2016. “Preparing Engineers for The Workplace Through Service Learning: Perceptions of EPICS Alumni." Journal of Engineering Education 105, no. 1: 43-69. https:// doi.org/10.1002/jee.20107 
Jackowski, Mick, and Laurie Gullion. 1998. "Teaching Sport Management Through Service-Learning: An Undergraduate Case Study." Quest 50, no. 3: 251-265. https: / / doi.org/10.1080/00336297.1998.10484284

Jia, Xiaokai, Jiyoon Jung, and Anne Ottenbreit-Leftwich. 2018. “Learning Technology Integration from A Service-Learning Project: Connecting Preservice Teachers to Real-World Problems." Journal of Experiential Education 41, no. 3: 261-276. https: / / doi.org/10.1177\%2F1053825917738269

Jones, Susan R., and Kathleen Hill. 2001. “Crossing High Street: Understanding Diversity Through Community Service-Learning." Journal of College Student Development 42, no. 3: 204-216.

Khelifa, Benahmed, Hafid Haffaf, Merabti Madjid, and David Llewellyn-Jones. 2009. "Monitoring connectivity in wireless sensor networks." In 2009 IEEE Symposium on Computers and Communications, 507-512. https:// doi.org/10.1109/ISCC.2009.5202236

Kirby, Sue, Fabian P. Held, Debra Jones, and David Lyle. 2018. “Growing Health Partnerships in Rural and Remote Communities: What Drives the Joint Efforts of Primary Schools and Universities in Maintaining Service Learning Partnerships?." Primary Health Care Research \& Development 19, no. 5: 503-517. https:/ / doi.org/10.1017/S146342361700086X

Knobloch, Neil A. 2003. "Is Experiential Learning Authentic?." Journal of Agricultural Education 44, no. 4: 22-34.

https: / / www.jae-online.org/attachments / article/327/44-04-22.pdf

Kraiger, Kurt, J. Kevin Ford, and Eduardo Salas. 1993. “Application of Cognitive, Skill-Based, and Affective Theories of Learning Outcomes to New Methods of Training Evaluation." Journal of applied psychology 78, no. 2: 311. https: / / doi.org/10.1037/0021-9010.78.2.311

Lancelot, William Henry. 1944. Permanent Learning; A Study in Educational Techniques. New York, NY: John Wiley \& Sons.

Larson, Grant. 2008. “Community Service Learning: What Does It Mean for Social Work Education?" Canadian Social Work Review/Revue Canadienne De Service Social 25, no. 1: 89-96.

Liberman, Sofia, and Roberto López Olmedo. 2017. "Psychological Meaning of "Coauthorship" Among Scientists Using the Natural Semantic Networks Technique." Social Epistemology 31, no. 2: 152-164.

https:// doi.org/10.1080/02691728.2016.1213329 
Lichtenstein, Michael J., Linda A. Pruski, Carolyn E. Marshall, Cheryl L. Blalock, Shuko Lee, and Rosemarie Plaetke. 2003. "Sentence Completion to Assess Children's Views About Aging." The Gerontologist 43, no. 6: 839-848. https:/ / doi.org/10.1093/geront/43.6.839

Lilley, Kathleen, Michelle Barker, and Neil Harris. 2017. “The Global Citizen Conceptualized: Accommodating Ambiguity." Journal of Studies in International Education 21, no. 1: 6-21. https:/ / doi.org/10.1177\%2F1028315316637354

Lin, Pearl MC, YongHee Kim, Hanqin Qiu, and Lianping Ren. 2017. “Experiential Learning In Hospitality Education Through A Service-Learning Project." Journal of Hospitality E Tourism Education 29, no. 2: 71-81. https: / / doi.org/10.1080/10963758.2017.1297716

Lopez, Christian E., Zixuan V. Zhao, and Conrad S. Tucker. 2019. “Semantic Network Differences Across Engineering Design Communication Methods." In International Design Engineering Technical Conferences and Computers and Information in Engineering Conference, vol. 59179, p. V001T02A030. American Society of Mechanical Engineers. https:// doi.org/10.1115/DETC2019-97728

Lozano, Sergi, Xosé-Pedro Rodríguez, and Alex Arenas. 2014. “Atapuerca: Evolution of Scientific Collaboration in An Emergent Large-Scale Research Infrastructure." Scientometrics 98, no. 2: 1505-1520. https: / / doi.org/10.1007/s11192-013-1162-x

Maloney, S. Margaret, and Kristen Griffith. 2013. “Occupational Therapy Students' Development of Therapeutic Communication Skills During a ServiceLearning Experience." Occupational Therapy in Mental Health 29, no. 1: 10-26. https: / / doi.org/10.1080/0164212X.2013.760288

McIntosh, Peggy. 2005. “Gender perspectives on educating for global citizenship." In Educating Citizens for Global Awareness, edited by Nel Noddings, 22-39. New York: Teachers College Press.

Mukherjee, Mousumi, Sangeeta Pethiya, and Vanthangpui Khobung. 2019. "Introduction to global citizenship education." In Global Citizenship Education: A Handbook for Teachers at Upper Primary Level In India, edited by Sangeeta Pethiya, and Soyhunlo Sebu, 6-10. Bhopal: Regional Institute of Education. http:/ / dspace.jgu.edu.in:8080/jspui/bitstream/10739/2665/1/Mukherjee IntroGlobalCitizenshipEducation.pdf 
Novak, Julie M., Vern Markey, and Mike Allen. 2007. “Evaluating Cognitive Outcomes of Service Learning in Higher Education: A MetaAnalysis." Communication Research Reports 24, no. 2: 149-157. https: / / doi.org/10.1080/08824090701304881

Ohara, Kouzou, Kazumi Saito, Masahiro Kimura, and Hiroshi Motoda. 2019. “Critical Node Identification based on Articulation Point Detection for Uncertain Network." International Journal of Networking and Computing 9, no. 2: 201-216. https://doi.org/10.15803/ijnc.9.2_201

Olivares Aguila, Jessica, and Waguih ElMaraghy. 2018. "Structural Complexity and Robustness of Supply Chain Networks Based on Product Architecture." International Journal of Production Research 56, no. 20: 6701-6718. https:// doi.org/10.1080/00207543.2018.1489158

Oxley, Laura, and Paul Morris. 2013. "Global Citizenship: A Typology for Distinguishing Its Multiple Conceptions." British Journal of Educational Studies 61, no. 3: 301-325.

https://doi.org/10.1080/00071005.2013.798393

Perra, Nicola, and Santo Fortunato. 2008. "Spectral Centrality Measures in Complex Networks." Physical Review E 78, no. 3: 036107. https:/ / doi.org/10.1103/PhysRevE.78.036107

Qualters, Donna M. 2010. "Making the Most of Learning Outside the Classroom." New Directions for Teaching and learning 2010, no. 124: 95-99. https: / / doi.org/10.1002/t1.427

R. Richards, Andrew K., Wesley J. Wilson, and Lori Eubank. 2012. "Planning A Service-Learning Program to Benefit Children with Disabilities." Journal of Physical Education, Recreation \& Dance 83, no. 7: 32-45.

https:// doi.org/10.1080/07303084.2012.10598810

Reeb, Roger N., and Susan F. Folger. 2013. "Community Outcomes of Service Learning." In Research on Service Learning: Conceptual Frameworks and Assessment 2, edited by Patti H. Clayton, Robert G. Bringle, and Julie A. Hatcher, 389-418. Virginia: Stylus Publishing.

Roberts, Jay W. 2015. Experiential Education in the College Context: What It Is, How It Works, And Why It Matters. Routledge.

Roodin, Paul, Laura Hess Brown, and Dorothy Shedlock. 2013. “Intergenerational Service-Learning: A Review of Recent Literature and Directions for the Future." Gerontology \& Geriatrics Education 34, no. 1: 3-25.

https: / / doi.org/10.1080/02701960.2012.755624 
Schattle, Hans. 2009. "Global Citizenship in Theory and Practice." In The Handbook of Practice and Research in Study Abroad: Higher Education and the Quest for Global Citizenship, edited by Ross Lewin, 3-20. New York: Routledge.

Schultz, Friederike, Jan Kleinnijenhuis, Dirk Oegema, Sonja Utz, and Wouter Van Atteveldt. 2012. "Strategic Framing in the BP Crisis: A Semantic Network Analysis of Associative Frames." Public Relations Review 38, no. 1: 97-107. https:// doi.org/10.1016/j.pubrev.2011.08.003

Schultz, Steven. 1999. "Where's the Learning in Service-Learning?" Review of Where's the Learning in Service-Learning?, by Janet Eyler and Dwight E. Giles, Jr., Michigan Journal of Community Service Learning 6, no. 1: 142-143. http://hdl.handle.net/2027/spo.3239521.0006.115

Schulz, Bernd. 2008. "The Importance of Soft Skills: Education Beyond Academic Knowledge." NAWA Journal of Language and Communication, June 2008: 146154.

http:/ / ir.nust.na/bitstream/10628/39/1/The $\% 20$ Importance $\% 20$ of $\% 20$ Soft $\% 20 \% 20$ Skills-Education $\% 20$ beyond $\% 20$ academic $\% 20$ knowledge.pdf

Shahzadi, Naseem, and Adil Shaheen. 2011. "Semantic Network Based Semantic Search of Religious Repository." International Journal of Computer Applications 36, no. 9: 1-5.

http:/ / citeseerx.ist.psu.edu/viewdoc/ download?doi=10.1.1.734.8385\&rep=re p1\&type $=$ pdf

Shellman, Stephen M., and Kürşad Turan. 2006. "Do Simulations Enhance Student Learning? An Empirical Evaluation of An IR Simulation." Journal of Political Science Education 2, no. 1: 19-32.

https://doi.org/10.1080/15512160500484168

Slantcheva-Durst, Snejana. 2018. "Semantic Networks of Student Journals." Journal of Pedagogy and Educational Management 2, no. 2: 27-38.

Smart, Paul R., Winston Sieck, Katia Sycara, and Nigel R. Shadbolt. 2010. “Semantic Networks and Shared Understanding: A Network-Based Approach to Representing and Visualizing Shared Understanding". 4th Annual Conference of the International Technology Alliance (ACITA'10), London, United Kingdom. 13 15 Sep 2010.

https:/ / eprints.soton.ac.uk/271452/1/Semantic Networksv3.pdf 
Soukup, Paul A. 1999. "Service-learning in Communication: Why." Voices of Strong Democracy: Concepts and Models for Service-Learning in Communication Studies: 7-12.

https: / / citeseerx.ist.psu.edu/viewdoc/download?doi=10.1.1.839.8724\&rep=r ep1\&type $=$ pdf \# page $=22$

Steinberg, Kathryn S., Robert G. Bringle, and Lisa E. McGuire. 2013. “Attributes of High-Quality Research on Service Learning." In Research on Service Learning: Conceptual Frameworks and Assessment 2, edited by Patti H. Clayton, Robert G. Bringle, and Julie A. Hatcher, 27-53. Virginia: Stylus Publishing.

Stimson, Rufus Whittaker. 1919. Vocational agricultural education by home projects. Macmillan.

Swords, Alicia C. S., and Richard Kiely. 2010. “Beyond Pedagogy: Service Learning as Movement Building in Higher Education." Journal of Community Practice 18, no. 2-3: 148-170.

https: / / doi.org/10.1080/10705422.2010.487253

Tucker, Mary L., and Anne M. McCarthy. 2001. “Presentation Self-Efficacy: Increasing Communication Skills Through Service-Learning." Journal of Managerial Issues 13, no. 2: 227-244.

https://www.jstor.org/stable/40604346

UNHCR. 2019. “The UN Refugee Agency - Turkey Fact Sheet” Accessed February 20, 2021.

https: / / reliefweb.int/sites/reliefweb.int/files/resources/UNHCR-TurkeyOne-Pager-Fact-Sheet-Oct2019.pdf

Valdes-Vasquez, Rodolfo, India Luxton, and Mehmet E. Ozbek. 2020. “Understanding the Learning Impacts of a Short-Term Study Abroad by Using a MixedMethod Approach." 14th International Technology, Education and Development Conference, March 2020. http:/ / doi.org/10.21125/inted.2020.0376

Valente, Thomas W., Kathryn Coronges, Cynthia Lakon, and Elizabeth Costenbader. 2008. "How Correlated Are Network Centrality Measures?." Connections (Toronto, Ont.) 28, no. 1: 16. https: / / www.ncbi.nlm.nih.gov/pmc/articles/PMC2875682/

Wang, Ying, and Ebru Genç. 2019. "Path to Effective Mobile Advertising in Asian Markets." Asia Pacific Journal of Marketing and Logistics 31, no. 1: 55-80. https: / / doi.org/10.1108/ APJML-06-2017-0112 
64 < ilef dergisi

We Are Social. (2020). “Digital 2020 - Global Digital Overview”. Accessed February 2, 2021.

https://wearesocial.com/digital-2020

Wey, Tina W., and Daniel T. Blumstein. 2010. "Social Cohesion in Yellow-Bellied Marmots Is Established Through Age and Kin Structuring." Animal Behaviour 79, no. 6: 1343-1352.

https:// doi.org/10.1016/j.anbehav.2010.03.008 
Table 1: Universities and courses included in the sample

\begin{tabular}{|c|c|c|c|c|}
\hline City & University & Type & Program & Course Name \\
\hline Ankara & A & Foundation & $\begin{array}{l}\text { Joint and Elective } \\
\text { Courses Unit }\end{array}$ & $\begin{array}{l}\text { Social Responsibility } \\
\text { Project }\end{array}$ \\
\hline Ankara & A & Foundation & $\begin{array}{l}\text { Public Relations } \\
\text { and Advertising }\end{array}$ & $\begin{array}{l}\text { Social Responsibility } \\
\text { Campaigns }\end{array}$ \\
\hline Ankara & B & Foundation & $\begin{array}{l}\text { Radio, Television } \\
\text { and Cinema }\end{array}$ & $\begin{array}{l}\text { Social Responsibility } \\
\text { Campaigns }\end{array}$ \\
\hline Ankara & B & Foundation & Social Services & $\begin{array}{l}\text { Volunteering and Social } \\
\text { Work }\end{array}$ \\
\hline Ankara & C & Foundation & $\begin{array}{l}\text { Joint and Elective } \\
\text { Courses Unit }\end{array}$ & \begin{tabular}{|l} 
Ethics and Social \\
Responsibility
\end{tabular} \\
\hline Ankara & D & State & $\begin{array}{l}\text { Joint and Elective } \\
\text { Courses Unit }\end{array}$ & Volunteer Works \\
\hline Ankara & $E$ & State & $\begin{array}{l}\text { Physical Education } \\
\text { and Sports } \\
\text { Teaching }\end{array}$ & Community Service \\
\hline Ankara & E & State & $\begin{array}{l}\text { Occupational } \\
\text { Therapy }\end{array}$ & Social Participation \\
\hline Ankara & $E$ & State & $\begin{array}{l}\text { Occupational } \\
\text { Therapy }\end{array}$ & $\begin{array}{l}\text { University Without } \\
\text { Barriers }\end{array}$ \\
\hline Bursa & F & State & Fine Arts Education & $\begin{array}{l}\text { Community Service } \\
\text { Applications }\end{array}$ \\
\hline Bursa & F & State & Food Engineering & $\begin{array}{l}\text { Social Responsibility } \\
\text { Applications }\end{array}$ \\
\hline Denizli & G & State & $\begin{array}{l}\text { English Language } \\
\text { and Literature }\end{array}$ & $\begin{array}{l}\text { Community Service } \\
\text { Practices }\end{array}$ \\
\hline Edirne & $\mathrm{H}$ & State & $\begin{array}{l}\text { University } \\
\text { Common Course }\end{array}$ & \begin{tabular}{|l} 
Business Ethics and Social \\
Responsibility
\end{tabular} \\
\hline Eskișehir & I & State & Social Services & Social Responsibility \\
\hline Eskișehir & J & State & $\begin{array}{l}\text { Visual } \\
\text { Communication } \\
\text { Design } \\
\end{array}$ & $\begin{array}{l}\text { Socially Responsible } \\
\text { Design }\end{array}$ \\
\hline İstanbul & K & State & $\begin{array}{l}\text { Guidance and } \\
\text { Psychological } \\
\text { Counselling } \\
\end{array}$ & Living with Disabilities \\
\hline İstanbul & K & State & $\begin{array}{l}\text { Guidance and } \\
\text { Psychological } \\
\text { Counselling }\end{array}$ & Community Involvement \\
\hline
\end{tabular}




\begin{tabular}{|c|c|c|c|c|}
\hline İstanbul & L & State & Communication & $\begin{array}{l}\text { Corporate Social } \\
\text { Responsibility (CSR) } \\
\text { Projects I }\end{array}$ \\
\hline istanbul & M & Foundation & Psychology & $\begin{array}{l}\text { Social Responsibility and } \\
\text { Community Service }\end{array}$ \\
\hline İstanbul & $N$ & Foundation & $\begin{array}{l}\text { Media and } \\
\text { Communication }\end{array}$ & $\begin{array}{l}\text { Service Practices and } \\
\text { Sustainability With } \\
\text { Community in Avcilar } \\
\text { Region }\end{array}$ \\
\hline istanbul & $N$ & Foundation & $\begin{array}{l}\text { Exercise and Sport } \\
\text { Sciences }\end{array}$ & $\begin{array}{l}\text { Volunteering and Social } \\
\text { Sensitivity Applications }\end{array}$ \\
\hline istanbul & 0 & Foundation & $\begin{array}{l}\text { Preschool } \\
\text { Education }\end{array}$ & $\begin{array}{l}\text { Community Service } \\
\text { Practices }\end{array}$ \\
\hline istanbul & 0 & Foundation & Child Development & $\begin{array}{l}\text { Community Service } \\
\text { Practices }\end{array}$ \\
\hline istanbul & 0 & Foundation & $\begin{array}{l}\text { Human Resources } \\
\text { Management }\end{array}$ & $\begin{array}{l}\text { Community Service } \\
\text { Practices }\end{array}$ \\
\hline İstanbul & $P$ & State & Primary Education & Community Service \\
\hline İstanbul & $P$ & State & $\begin{array}{l}\text { Public Relations } \\
\text { and Advertising }\end{array}$ & $\begin{array}{l}\text { Social Responsibility } \\
\text { Communication }\end{array}$ \\
\hline istanbul & $P$ & State & Nursing & $\begin{array}{l}\text { Consciousness of Social } \\
\text { Responsibility }\end{array}$ \\
\hline İstanbul & $P$ & State & Business & $\begin{array}{l}\text { Corporate Social } \\
\text { Responsibility }\end{array}$ \\
\hline İstanbul & $P$ & State & $\begin{array}{l}\text { Physiotherapy and } \\
\text { Rehabilitation }\end{array}$ & $\begin{array}{l}\text { Social Responsibility } \\
\text { Concept }\end{array}$ \\
\hline istanbul & $P$ & State & $\begin{array}{l}\text { Corporate } \\
\text { Communication }\end{array}$ & $\begin{array}{l}\text { Social Responsibility and } \\
\text { Project Management }\end{array}$ \\
\hline İstanbul & $P$ & State & Sociology & $\begin{array}{l}\text { The Civil Society and } \\
\text { Voluntariness }\end{array}$ \\
\hline İstanbul & $R$ & Foundation & $\begin{array}{l}\text { Public Relations } \\
\text { and Information }\end{array}$ & $\begin{array}{l}\text { Communication for Social } \\
\text { Good }\end{array}$ \\
\hline İstanbul & $R$ & Foundation & $\begin{array}{l}\text { University } \\
\text { Common Course }\end{array}$ & Civic Responsibility Project \\
\hline Istanbul & $\mathrm{S}$ & State & $\begin{array}{l}\text { Joint and Elective } \\
\text { Courses Unit }\end{array}$ & $\begin{array}{l}\text { Community Service } \\
\text { Practices }\end{array}$ \\
\hline İstanbul & $\mathrm{S}$ & State & $\begin{array}{l}\text { Health } \\
\text { Management }\end{array}$ & $\begin{array}{l}\text { Social Responsibility } \\
\text { Project }\end{array}$ \\
\hline İstanbul & $T$ & Foundation & Business & $\begin{array}{l}\text { Corporate Social } \\
\text { Responsibility }\end{array}$ \\
\hline İstanbul & $T$ & Foundation & $\begin{array}{l}\text { Public } \\
\text { Administration }\end{array}$ & $\begin{array}{l}\text { Social Responsibility } \\
\text { Projects }\end{array}$ \\
\hline
\end{tabular}




\begin{tabular}{|c|c|c|c|c|}
\hline İstanbul & $T$ & Foundation & $\begin{array}{l}\text { English Language } \\
\text { Teaching }\end{array}$ & Social Awareness \\
\hline istanbul & $U$ & State & Graphic Design & $\begin{array}{l}\text { Social Responsibility and } \\
\text { Design }\end{array}$ \\
\hline İstanbul & $U$ & State & $\begin{array}{l}\text { Political Science } \\
\text { and International } \\
\text { Relations }\end{array}$ & Civic Involvement I \\
\hline İstanbul & U & State & $\begin{array}{l}\text { Political Science } \\
\text { and International } \\
\text { Relations }\end{array}$ & Civic Involvement II \\
\hline Istanbul & $U$ & State & $\begin{array}{l}\text { Elementary } \\
\text { Mathematics } \\
\text { Education }\end{array}$ & $\begin{array}{l}\text { Community Service } \\
\text { Applications }\end{array}$ \\
\hline istanbul & $U$ & State & $\begin{array}{l}\text { Preschool } \\
\text { Education }\end{array}$ & $\begin{array}{l}\text { Community Service } \\
\text { Applications }\end{array}$ \\
\hline istanbul & $U$ & State & $\begin{array}{l}\text { Foreign Languages } \\
\text { Education }\end{array}$ & $\begin{array}{l}\text { Community Service } \\
\text { Applications }\end{array}$ \\
\hline İzmir & V & State & $\begin{array}{l}\text { Departments of } \\
\text { Faculty of Business }\end{array}$ & $\begin{array}{l}\text { Social Responsibility } \\
\text { Project }\end{array}$ \\
\hline İzmir & V & State & $\begin{array}{l}\text { Maritime Business } \\
\text { Management }\end{array}$ & $\begin{array}{l}\text { Corporate Social } \\
\text { Responsibility }\end{array}$ \\
\hline Izmir & V & State & Archaeology & Social Responsibility \\
\hline İzmir & W & State & $\begin{array}{l}\text { Joint and Elective } \\
\text { Courses Unit }\end{array}$ & Community Service \\
\hline İzmir & $x$ & Foundation & $\begin{array}{l}\text { Public Relations } \\
\text { and Advertising }\end{array}$ & $\begin{array}{l}\text { Civic Participation and } \\
\text { Volunteerism }\end{array}$ \\
\hline İzmir & $x$ & Foundation & $\begin{array}{l}\text { Public Relations } \\
\text { and Advertising }\end{array}$ & Volunteer Works \\
\hline İzmir & $Y$ & Foundation & $\begin{array}{l}\text { Industrial } \\
\text { Engineering }\end{array}$ & Social Responsibility \\
\hline Kars & Z & State & $\begin{array}{l}\text { Guidance and } \\
\text { Psychological } \\
\text { Counselling }\end{array}$ & $\begin{array}{l}\text { Community Service } \\
\text { Practices }\end{array}$ \\
\hline Kırșehir & AA & State & $\begin{array}{l}\text { Turkish Language } \\
\text { Teaching }\end{array}$ & $\begin{array}{l}\text { Community Service } \\
\text { Practices }\end{array}$ \\
\hline Kocaeli & $A B$ & State & Business & \begin{tabular}{|l|} 
Corporate Social \\
Responsibility
\end{tabular} \\
\hline Mersin & $A C$ & State & $\begin{array}{l}\text { Tourism } \\
\text { Management }\end{array}$ & $\begin{array}{l}\text { Social Responsibility } \\
\text { Project }\end{array}$ \\
\hline
\end{tabular}




\begin{tabular}{|l|l|l|l|l|}
\hline Muğla & AD & State & $\begin{array}{l}\text { Physical Education } \\
\text { and Sports } \\
\text { Teaching }\end{array}$ & $\begin{array}{l}\text { Community Service } \\
\text { Practices }\end{array}$ \\
\hline Muğla & AD & State & $\begin{array}{l}\text { Tourism } \\
\text { Management }\end{array}$ & $\begin{array}{l}\text { Social Responsibility } \\
\text { Project }\end{array}$ \\
\hline Muğla & AD & State & Nursing & $\begin{array}{l}\text { Individual Development } \\
\text { and Social Responsibility }\end{array}$ \\
\hline Sakarya & AE & State & $\begin{array}{l}\text { Guidance and } \\
\text { Psychological } \\
\text { Counselling }\end{array}$ & $\begin{array}{l}\text { Community Service } \\
\text { Practices }\end{array}$ \\
\hline Sakarya & AE & State & $\begin{array}{l}\text { University } \\
\text { Common Course }\end{array}$ & Social Responsibility \\
\hline Sanlıurfa & AF & State & $\begin{array}{l}\text { Agricultural } \\
\text { Economics }\end{array}$ & $\begin{array}{l}\text { Social Responsibility } \\
\text { Projects }\end{array}$ \\
\hline Van & AG & State & $\begin{array}{l}\text { Departments } \\
\text { of Faculty of } \\
\text { Engineering and } \\
\text { Architecture }\end{array}$ & $\begin{array}{l}\text { Social Responsibility } \\
\text { Project }\end{array}$ \\
\hline Van & AG & State & $\begin{array}{l}\text { Property } \\
\text { Protection and } \\
\text { Safety }\end{array}$ & $\begin{array}{l}\text { Social Awareness } \\
\text { Business }\end{array}$ \\
\hline Yozgat & AH & State & $\begin{array}{l}\text { Social Responsibility and } \\
\text { Ethics }\end{array}$ \\
\hline
\end{tabular}

